\section{SOI: $1.1 /$ TAS DOI: $10.15863 / \mathrm{TAS}$ International Scientific Journal Theoretical \& Applied Science}

p-ISSN: 2308-4944 (print) e-ISSN: 2409-0085 (online)

Year: $2018 \quad$ Issue: $01 \quad$ Volume: 57

Published: $30.01 .2018 \quad$ http://T-Science.org

SECTION 21. Pedagogy. Psychology. Innovations in the field of education
Tatyana Prochorovna Savitskaya Associate professor, PhD in Philological sciences, The Kosygin State University of Russia, 1golub@mail.ru

Elena Vladimirovna Kazakova Associate professor, The Kosygin State University of Russia, el.kazackova@yandex.ru

Vladimir Vladimirovitch Zotov Associate professor, $\mathrm{PhD}$ in Economic sciences The Kosygin State University of Russia, vvzotov777@yandex.ru

Aleksey Yevgenyevitch Popel Associate professor, $\mathrm{PhD}$ in Culturology The Kosygin State University of Russia, popel_a_e@mail.ru

\title{
METAPHOR AS AN INSTRUMENT OF KNOWLEDGE
}

Abstract: The subject of the article is the consideration of metaphor as a means of verbalizing new concepts, a way of forming and expanding knowledge of the surrounding reality, as well as defining the role of metaphor in the conceptual field on the examples of Russian and English languages. The significance of metaphor as a valuable tool for students learning foreign languages is presented.

Key words: metaphor, cognition, conceptual, mental connections, interaction, cognitive process, conceptual metaphor, concept, creation of terminology.

Language: English

Citation: Savitskaya TP, Kazakova EV, Zotov VV, Popel AY (2018) METAPHOR AS AN INSTRUMENT OF KNOWLEDGE. ISJ Theoretical \& Applied Science, 01 (57): 126-132.

Soi: http://s-0-i.org/1.1/TAS-01-57-23 Doi: crossef https://dx.doi.org/10.15863/TAS.2018.01.57.23

\section{Introduction}

The traditional definition of a metaphor is based on a shift in the meaning of a word to express a new concept or phenomenon by means of the language $[1$, 94]. A necessary condition for the verbalization of the new concept is the existence of associative links with the original word, based either on the external similarity or similarity of the function of the given concept with the well-known one. In many cases the metaphorical transfer of meanings, manifested primarily at the level of speech, gradually becomes the property of the language and finds its reflection both in everyday speech and the formation of a specialized terminology, and the creation of special reference books. Agreeing with the opinions of scientific researchers that the metaphor is the basis for creation of new concepts and their notation in the language, we would like to emphasize the role of metaphor as a method of teaching foreign-language communication in the process of cognition of the surrounding reality. Providing an understanding of the processes and essence of phenomena not only at the level of everyday communication, but also at the level of professional communication, the metaphor helps to increase the motivation for learning a foreign language and developing metaphorical thinking. In order to more clearly define the place of the metaphor in the educational process more clearly, it is necessary to dwell briefly on the essence of the metaphor and the features of the metaphorical thinking in both everyday life and the study of concepts and phenomena in the sublanguages of a special branch.

\section{Materials and methods}

When speaking about the definition of metaphor the cognitive approach to the study of metaphorization processes, which is based on the study of thinking process, is becoming increasingly widespread. The metaphor is defined as a way of recognizing and explaining the picture of the world in which a person lives, and is considered to be one of the basic mental operations. "Man not only expresses his thoughts using metaphors, using their aesthetic potential, but he also thinks with metaphors, he explores the world he lives in with their help" [2, 55].

The psychological aspect of metaphors functioning was developed in the works of $\mathrm{E}$. McKormack, who believed that to reveal the essence 
of metaphorical transfer, it is necessary to assume the presence of cognitive structures of our thinking "as a device that generates language" [3, 359]. In his works the author defines the metaphor as a cognitive process, necessary for conveying the novelty of knowledge, and whose essence is determined by the unity of the two processes - cognitive and semantic. The conceptual world of man reflects the features of man, his being, interaction with the surrounding world in constantly developing and changing conditions of existence. Accordingly, any changes in the life of society are reflected in the language, its structure and semantics, causing the creation of conceptual metaphors and conceptual fields in the field of intellectual activity. The origin of the metaphor is rooted in the juxtaposition of incompatible semantic concepts in the human mind through certain mental operations. On the one hand, since it must be understood the metaphor implies a similarity between the properties of its semantic referents, but on the other hand, it stresses the dissimilarity between them, since the metaphor is meant to create some new meaning.

Among a large number of theoretical studies of metaphor from the point of view of the cognitive approach, one of the main ones is the theory of interaction $[4,213]$, which is based on the approach to metaphor as a result of the associative interaction of two figurative or conceptual systems, the designated and figurative means. The projection of one of the two systems onto the other ones gives a new look at the object and makes the metaphor denoted by the new verbalized concept. According to this theory, the metaphorical transfer is based on the borrowing and interaction of ideas (thoughts) and the change of context, because the idea is "metaphorical and develops through an associative comparison, and hence metaphors appear in the language" $[4,46]$.

In case of the anthropological approach [5, 256] to the study of metaphor, the sources of it lie in the peculiarities of human consciousness and perception of the world, in the laws of the emergence of images and concepts, reflected in the thinking of an individual. Since the nature of the metaphor is not linguistic, but conceptual, it is often the metaphor that makes it possible to comprehend an abstract phenomenon or a non-structured object by means of a more concrete and structured one. The interpretation of metaphors becomes possible due to the presence of a system of basic concepts common to all members of a certain community. To form the concepts and their existence, the language itself is not needed. When exchanging thoughts and discussing them in the process of communication these concepts must be verbalized, i.e. expressed by means of language, which can be done by individual words and phrases, phraseological units, sentences and whole texts. In the case of the primary nomination, the transfer of a specific concept, for example, "apple" (яблоко) is not difficult. It is enough to know the meaning of the word, which activates this image. However, as the initial value is correlated with another reality and the secondary nomination is formed, it becomes necessary to activate mental activity and search for the necessary means of language to denote a new reality. In English, you can identify a number of metaphors, denoting a variety of really existing concepts correlated with the "apple" by some associations. For example: "Adam's apple" (кадык); the apple of an eye (зрачок); apple of discord (яблоко раздора); a bad apple (негодяй); apple-green (зеленый цвет лица, кислое яблоко); a dumpling apple (морщинистый, как яблоко). In this case a secondary nomination takes place. As a result specific metaphors are formed, so called conceptual ones (eg. apple of discord). To understand a simple metaphor it is sufficient to point out the characteristic feature underlying the semantic shift of meaning, while the interpretation of the conceptual metaphor requires the interpretation of a certain number of situations, by means of which it is possible to reveal its meaning. The "apple of discord" may mean a misunderstanding among people trying to solve problems, different views on property, different attitudes towards certain events. (Compare: the situation in the Ukraine served as an apple of discord for many previously close people). The verbalization of the metaphorically formed conceptual notion is mainly through combinations of words.

The abstract concept, as a rule, is metaphorized only in certain contexts, its description requires the description of the situation. For example, considering the associations that arise to understand the abstract concept of "satisfaction" (удовлетворение), one can imagine "the inner, weak, partial, complete, unexpected satisfaction" (внутреннее, слабое, частичное, полное, неожиданное удовлетворение). The character of the feeling, its strength and fullness can be realized only with reference to the situation in which this feeling has appeared. For example: 1. They found a secret satisfaction watching the girl speaking to her toy. 2 . We expect some satisfaction for our losses. In the first situation: the feeling is deeply hidden; the feeling lasts for a while; the girl does not notice people looking at her; the girl is unaware of the feeling; the girl is obviously small. In the second case, the losses suffered are significant, but there is a hope that they will be at least partially compensated. Understanding of deep metaphorical connections between the realities of the situation helps to understand the situation itself and that plays an important role in the process of learning a foreign language.

Metaphors can provide new terminology for various branches of national economy and science. Most of the emerging metaphoric terms are due to 
the fact that the metaphor reflects the ability of a person to transfer everyday experience to a special field of activity, revealing the similarity between very different individuals and objects and denoting this similarity by means of the language. For example, in the field of information technology (IT), many metaphoric terms, such as "window" (окно), "menu" (меню), "memory" (память), “dialog" (диалог), "virus" (вирус), "mouse" (мышка) have become widespread in the Russian language and have become an integral part of the language and thinking. As it has already been mentioned, the metaphorization of new concepts is conditioned by the presence of associative links with the original word which are based either on external similarity of the concepts or the similarity of their functions. In the English language, more metaphorical by its nature, as well as in Russian, there is a large number of metaphorical terms in the sublanguages of branch terminologies. For example, in the automotive industry - "a disk pad" (колодка тормозного диска); "axle pad" (рессорная подушка); "accelerator pedal pad" (упор для ноги около педали газа); in the economy - "elastic demand" (спрос реагирующий на повышение или понижение цен); “joint demand” (спрос на сопряженные товары); "time-off demand" (требования о сокращении рабочего времени); in railway terminology - "frog" (крестовина ж/д стрелки). The latter example is based on a metaphorical transfer, similar to a "frog jump", since the main purpose of the "arrow" on the railroad tracks is a sharp transfer of the train from one track to another one. In the Russian language, the creation of the term was based on external similarity.

The metaphorical shift of meaning can be conditioned by the subjective perception of similar associative features. Quite often the associated similarity may not be related to the concept of a particular object or phenomenon, but is caused by a subjective representation of a person perceiving new entities in certain circumstances. In this case the name obtained as a result of the metaphorical transfer of the associative sign does not show the object itself, but "the usual fixed relation of the given language community to it" $[8,55]$. There are several examples in the Russian language from the field of business communication: "moose" (руководитель среднего звена); “deer” (руководитель высшего звена); “animal” (невменяемый руководитель, хам, грубиян); “bear” (неуклюжий, неловкий). In English - "lame duck" (человек или фирма в тяжёлом финансовом положении; биржевый маклер, не способный выполнить обязательства по заключённым сделкам); "fat cat" (состоятельный бизнесмен, думающий лишь о собственной выгоде; «денежный мешок»); "rainmaker" (человек, приносящий компании значительную прибыль; бизнесмен со связями, лоббирующий интересы компании).

Having appeared as instruments of scientific knowledge, the terminological conceptual metaphors allow us to get a clear idea of the conceptual system of the given science, forming the terminology of a particular scientific field. [10, 340] However, due to the isomorphism of everyday representation and a specific nature of the concept, different languages use a metaphorical way of forming terms according to their thinking and perception of the world. In particular, we can note that English terms have greater associativity than their Russian counterparts. The term can be metaphorical in one language and not metaphorical in the other one. For example, the "egg insulator" - «орешковый изолятор» - is associated with an egg in English, in the Russian language - with a nut; "bell insulator" - «юбочный изолятор» - is similar to a bell in the opinion of the British people while in the Russian language there is an association with a skirt. The form of the insulator does not contradict both associations. The reason for the imbalance of terminological metaphors in the Russian and English languages is the specific vision of the world by people of different nationalities. For example, some railway terms, which are based on the concept of "head", are formed on the basis of various associations in English and in Russian terminology. In the common sense, the "head" can be associated with the concept "top", "beginning", "rounded form", "sphere". The concept of "beginning" in Russian is associated with such metaphors as "head car" (головной вагон), "head of the train" (голова поезда); similarity in form led to the creation of a metaphor "buffer head" (буферная тарелка). In English the concept "head" is associated with the notion of "top": “company head" (глава компании), “coupler head" (головка автосцепки).

The formation and functioning of terminological metaphors within the framework of branch conceptual fields has been the subject of scientific research in the study of the terminology of shipbuilding, automotive industry, agriculture, rail transport, etc. $[11,340 ; 12,74]$. Most of the terms that appeared at the initial stage of the formation of a new industry or science are metaphorically related, first of all, to the specifics of the organization and functioning of the industry. So, in railway industry, for example, it was important for railway men to find names related to locomotive and car building, the first vehicles and other items that required their names. Noting the similarity between a new concept, an object or a living being a man gave old, familiar names to new realities. Thus such terms as: «головка рельса» - “rail head", «подошва рельса» - "rail sole", «гребень колеса» - "wheel ridge”, «земляное полотно» - "earthen cloth", «подушка» - "cushion", «костыль» - “crutch", «тормозной башмак» “brake shoe", «паровой рукав» - "steam sleeve", 
«барабан котла» - “boiler drum”, «паровозная тележка» - "locomotive trolley", etc. appeared in the Russian and English languages. The extensive anthropometric nature of the terms-metaphors, as the most typical parameter for metaphors is a characteristic feature of both English and Russian terminology. This includes the names of parts of the human body, its status, state, actions inherent in the person, etc. In English they are: rail sole, rail head, circuit arm, gear train, bare wire, rail profile, crankshaft, cam contactor, blind intersection of paths, hostile route, power source, idling. Nature, its flora and fauna are an inexhaustible source of metaphors formation. Examples from Russian are барашковый винт (a wing screw), хвостовой вагон (a tail car), сотовая связь (a cellular connection). финансовые реки (financial rivers).

Examples in English include: dark horse, under a boiling sun, loan shark, butterflies in the stomach, beat the bushes, apple of my eye.

Household items and other everyday items that make up the world of the native speaker, were also widely used as prototypes for the formation of metaphorical terms. In Russian: костыль (crutch), вилка (fork), тормозной башмак (brake shoe), ленточный кабель (ribbon cable), колоколообразный (юбочный) изолятор (skirted insulator). In English: home signal, belt line, breaking shoe, threshold signal, sorting yard, petticoat insulator. Coloristic terms are another source of metaphorical terms in the conceptual field of industrial terminology and are characteristic, first of all, for those industries where color is the most important category. So in rail transportation the main purpose of which is traffic safety, the entire alarm system relies on color terms. In particular, prohibitive and permissive commands for the movement and maneuvering of trains are given by means of color.

As it has been mentioned above, the metaphor, first of all, satisfies the vital needs of cognition both in everyday and in scientific speech. However, in the language of science, the metaphor serves not only to refer to new concepts and realities. The metaphorical interpretation of existing units of language occurs as a result of the establishment of more or less complex mental connections between things and phenomena of the surrounding world during the process of reality cognition. In the language of science, as in everyday life, any neologism is metaphorical by its nature, and metaphorization is a universal process conditioned by the specificity of scientific knowledge by the language itself $[11,340]$. "The mapping of one conceptual domain onto another, a kind of expansion of the concepts of the source domain is taking place. The whole conceptual frame activated in consciousness by some word due to the associative connection of the given word to the conceptual structure and not an isolated name is transferred" [13,
352]. Both the creators of terms and users of terminology comprehend the essence of realities denoted by the conceptual metaphor in the process of cognition.

The practice of teaching a foreign language, practicing everyday speech and understanding terminology proves the necessity of studying metaphors of the language. Experience in teaching foreign language shows that Russian learners have comprehension problems studying metaphoric models due to cross-cultural differences. Nevertheless, we should consider the potential of metaphors as a pedagogical aid, because they shape our experience improve language skills, encourage critical thinking and problem-solving. The metaphor system plays a great role in studying both grammar and lexicon of a foreign language. Metaphoric models often play an important role in devising and communicating new knowledge and new discoveries in scientific theories, provide new specialized terms for newly developed fields of science and technology. By means of metaphors the structures from one conceptual domain are mapped to another one, thus we can better understand one type of experience by means of another.

The technique of brainstorming proved to be rather effective when at the first stage of studying the conceptual metaphors students try to guess their meaning independently. Further semantization of the metaphor meaning involves mental activity in identifying the entire list of concepts and words necessary for deeper understanding of the concept and reproducing of the situation (conceptual field) for its representation. The verbalization of the concept, complicated by the omission of certain attributes that are significant for understanding metaphors and the need to restore them is another recommended method of activating the mental associations necessary for understanding the metaphor, the concept expressed by it and the corresponding conceptual connections. The use of metaphor in a dialogical or monological speech testifies to a deep understanding of the linguistic unit and the formation of linguistic competence.

Attention given to the appearance and functioning of the language units is relevant. With the development of industry and other changes in the life of society, the process of new terms and concepts formation continues, and the metaphorical transfer of meaning still plays a major role. The metaphorical models allow to define a new concept economically (from the point of view of the use of linguistic means), accurately and clearly. Another function of the metaphor in cognizing reality is that it "serves as an instrument of thought by which we manage to reach the remotest parts of our conceptual field. Objects that are close to us, that are easily comprehended, open our thoughts and access to 
distant and elusive concepts. The metaphor lengthens the arm of the "intellect" [14, 72].

However, the concepts that govern our thought are not only the issues of intellect. Concepts also govern our daily activities. Most of the cases that we deal with every day, what we think about, what we do and how we know the surrounding reality, are more or less automatic in accordance with the experience. Our concepts structure what and how we perceive and how we treat other people. In other words, our conceptual system plays the central role in determining our everyday realities. The mechanism for the formation of human concepts and emotions is not obvious, and since the conceptual system of man is largely metaphoric, one way to understand the principle of this mechanism is to consider the use of the language within the conceptual field. It is verbalized by means of language and the cognitive mechanism that is used by man in his thinking and action for the functioning of this field.

To understand how the principle of this mechanism operates we can analyze cognitive relationships within the concept of "money" (деньги) [6, 72]. As a result of visual perception of "money" and the experience of handling it, numerous names were formed, combined into frame "paper", "metal", "greens", "grease", “cabbage". For example, the word "grease" for the name of "money" appeared on the basis of widespread knowledge and experience that any fat, lard or grease have the ability to enhance the sliding on the surface and facilitate movement on the surface. Considering "money" from this point of view, a person compares "money" with something known, which really helps to ease the course of some case. Another name for "money" "cabbage" (капуста) appeared because of the similarity of color (green cabbage) between cabbage and paper money. Perhaps, it is also important to mention that money is also pleasant to the touch, like the leaves of cabbage. The presence of a common semantic component in all these names indicates the existence of a conceptual metaphor associated with the concept of "money". A conceptual metaphor implies the presence of similarity between the properties of its semantic referents, since it must be understood. On the other hand, there is dissimilarity between them, since the metaphor is used to create some new meaning.

Associative links of the concept "money" as a conceptual metaphor allow determining the structure and scope of the conceptual field and creating "mental pictures" of human interaction with this concept. The metaphorical comprehension of reality is reflected in verbalized mental connections and awareness of how thought is reflected in the language. For example, associative links of the word "money" (деньги), considered within the conceptual field, show that the given word and its synonyms, most often, perform the role of an object that undergoes a certain action. Money may be received, saved, taken, invested, counted, hated. Money can be the object of love, sympathy, hatred, envy. As a resource word, money is combined with such predicates as saving, saving, earning, spending. At the same time, money can act as a kind of figure, resembling a living being. There is a metaphorical rethinking and as a subject of the action money can enter into relations with other entities. Money kills, buys, gives support, comes back, disappears, gets lost, changes hands, fails, keeps coming, talks, etc. In all these situations, money seems to come alive and get the properties of a person, and the metaphorical transfer of meaning serves to personalize money and emphasize its importance. A man thinks of money as a person who can make him happy, upset, disappoint and even destroy. The use of a word in the metaphorical perspective is often the only way to convey something important and essential to most people, since a common word attracts attention only when it is used in an unexpected sense. Personification of money is possible, most likely because, observing the surrounding reality, man perceives money as something essential, necessary and empowers it with power.

Conceptual metaphors are so natural and so deeply permeate our thinking that, as a rule, its "metaphoricity" is not recognized by native speakers; they are understood as self-evident, as a direct description of certain phenomena of the man's inner world. Conceptual metaphor allows to understand such abstract entities as top, bottom, time, emotions, morality, politics, happiness, hope and others through physical, sensory experience. Being conceptual metaphors, the words "top" and "bottom" have quite definite connotations - "top is good" and "bottom is bad". High (top) social position is correlated in consciousness with a comfortable existence, the possibility not to work (or work a little), the presence of moral qualities, education, power, and belonging to the lower (bottom) classes is associated with poverty, hard work, crime, immorality, dependent position, etc.

The conceptual system of man is metaphorically structured and more or less defined, and the understanding of the system functioning is based on the conscious (and sometimes unconscious) use of associative thinking processes and connections operating within a certain conceptual field. The thinking processes, being metaphorical and interconnected in nature, are the basis for the formation both of new concepts (conceptual metaphors) and conceptual fields. To understand how metaphorical models can give us the idea of the metaphorical nature of concepts and their interaction in everyday reality, we can consider the conceptual metaphor of "time is money", and how the concepts of "money" and "time" conform within a single 


\begin{tabular}{|c|c|c|c|c|c|c|}
\hline Impact Factor: & $\begin{array}{l}\text { ISRA (India) } \\
\text { ISI (Dubai, UAE } \\
\text { GIF (Australia) } \\
\text { JIF }\end{array}$ & $\begin{array}{r}=1.344 \\
=0.829 \\
=0.564 \\
=1.500\end{array}$ & $\begin{array}{l}\text { SIS (USA) } \\
\text { PИНЦ (Russia) } \\
\text { ESJI (KZ) } \\
\text { SJIF (Morocco) }\end{array}$ & $\begin{array}{l}=0.912 \\
=0.207 \\
=4.102 \\
=\mathbf{2 . 0 3 1}\end{array}$ & $\begin{array}{l}\text { ICV (Poland) } \\
\text { PIF (India) } \\
\text { IBI (India) }\end{array}$ & $\begin{array}{l}=6.630 \\
=1.940 \\
=4.260\end{array}$ \\
\hline
\end{tabular}

conceptual field $[6,256]$. The examples below, correlated with "time" and "money", illustrate the variety of actions and feelings that arise in a person in a given situation.

"You are wasting my time" («Вы отнимаете (букв. растрачиваете) мое время»). "This gadget will save you hours” («Это устройство сэкономит вам много времени»). "How do you spend your time these days?” («Как вы сейчас проводите тратите своё время?»). "This flat tire cost me an hour" («Спустившаяся шина стоила мне часа работы»). "Не is living on borrowed time" («ОH живет за счет чужого (букв. одолженного) времени»).

The variety of associative links between the concept of "time" and the concept of "money" is based on common or similar associations with the "need, importance, limitation of both time and money", thus creating stable correspondences between them. The metaphorical expressions of the verbal expression of concept "time is money" are correlated in some cases with a specific understanding of "money" (spend, invest, budget, profit, value); in other cases, with limited resources (use, have, quantity, insufficient, end); in the third with valuable goods (to have, to give, to lose). The presence of well-established associative connections in the conceptual field of the conceptual metaphor "time is money" testifies to the existence of a deep inner connection between the thinking processes and relations that a man has in language and thinking when he compares two concepts as a result of multilateral experience.

\section{Conclusions}

Summarizing the above mentioned, we would like to draw attention to the following:

1. The essence of metaphor is the comprehension and experience of phenomena of one kind in terms of another kind. The system of the native language, as well as the system of a foreign language, is a fairly broad "set" of names of objects and phenomena that are metaphorical in nature and formed by the semantic shift of already existing words in the language.

2. Metaphors as linguistic expressions become possible precisely because the conceptual system of a man, which is based on a person's ability to measure new phenomena and concepts through the prism of his views and knowledge, in the image and likeness of well-known things and phenomena is metaphorical. Since language communication is based on the conceptual system of a man, language acts as the most important source of information about what this system is.

3. The concept of a conceptual metaphor is correlated with the concept of a conceptual field. Understanding the peculiarities of the formation of such fields greatly expands the man's cognitive abilities not only in everyday life, but also in the scientific sphere. Awareness of conceptual fields in the cognition of new realities makes it possible to understand extremely complicated situations, phenomena and abstract concepts both in the native, and in the foreign languages.

4. Since the understanding of the deep links between the units of language within the conceptual field is the basis of linguistic competence, the cognitive approach to learning a foreign language would promote a deeper awareness of the associative links between different concepts and, accordingly, the formation of linguistic competence of the learners.

5. Metaphorical models have an important scientific function. To communicate new knowledge scientists frequently use metaphorical terms from the domain of other sciences. Metaphorical models shape our experience of the world and determine our world. By describing unknown knowledge by means of the known, scientists try to facilitate the communication process.

\section{References:}

1. Shmelev D.N. (2008) Problems of the semantic analysis of vocabulary (on the material of the Russian language). LKI, p.94.

2. Chudinov A.P. Budaev E.V. (2007) Cognitive theory of metaphor at the present stage of development. V sbornike:
Questions of cognitive linguistics, Moscow, p.52-57.

3. McCormack. (1990) Cognitive theory of metaphor. V sbornike: Theory of metaphor. Edited by Arutyunova I.D. and Zhurinskaya M.A., Moscow, Progress, p.359.

4. Black M. (1990) Metaphor. V sbornike: Theory of metaphor. Edited by Arutyunova 


\begin{tabular}{l|lr|ll|ll} 
& ISRA (India) & $=\mathbf{1 . 3 4 4}$ & SIS (USA) & $=\mathbf{0 . 9 1 2}$ & ICV (Poland) & $=\mathbf{6 . 6 3 0}$ \\
Impact Factor: & ISI (Dubai, UAE) $=\mathbf{0 . 8 2 9}$ & PUH (Russia) $=\mathbf{0 . 2 0 7}$ & PIF (India) & $=\mathbf{1 . 9 4 0}$ \\
& GIF (Australia) & $=\mathbf{0 . 5 6 4}$ & ESJI (KZ) & $=\mathbf{4 . 1 0 2}$ & IBI (India) & $=\mathbf{4 . 2 6 0}$ \\
& JIF & $=\mathbf{1 . 5 0 0}$ & SJIF (Morocco) & $=\mathbf{2 . 0 3 1}$ & & \\
\hline
\end{tabular}

I.D. and Zhurinskaya M.A., Moscow, Progress, p.213.

5. Richards A. (1990) Philosophy of rhetoric. V sbornike: Theory of metaphor. Edited by Arutyunova I.D. and Zhurinskaya M.A., Moscow, Progress, p.256.

6. Lakoff G., Johnson M. (2003) Metaphors we live by. LKI, p.256.

7. Ricker P. (1990) The metaphorical process is cognition, imagination and sensation. $\mathrm{V}$ sbornike: Theory of metaphor. Edited by Arutyunova I.D. and Zhurinskaya M.A., Moscow, Progress, p.512.

8. Anglo-Russian Dictionary of Economics and Finance. Edited by Anikin A.V. (1993) St. Petersburg, The School of Economic Press, p.55.

9. Ufimtseva A.A. (1997) Russians: the experience of one's self-knowledge. Etnokulturnaya specifika yazikovogo soznaniya, Moscow, p.139-163
10. Longman English Larousse. (1973) Great Britain, Hazell Watson \& Vinery Ltd, Eynesbury, Bucks, p.340

11. Chernysheva L.A. (2011) Anthropological aspects of modern branch terminology: on the material of the terminology of railway transport. The dissertation of the doctor of philological sciences, MGOU, Moscow, p.340.

12. Novikova T.A. (2005) Methods of the formation of railway terminology. In the journal "Railway Transport", Moscow, No.9, p.74.

13. Alekseeva L.M. (1998) Metaforitcheskoye terminoporozhdenie $\mathrm{i}$ funktsii terminov $\mathrm{v}$ tekste. Dissertatsiya doctora filologitcheskih nauk, Perm, p.352.

14. Kobozeva I.M. (2002) Linguistic semantics. Editorial. Moscow, URSS, p.72. 